\title{
ANTIBACTERIAL CHARACTERISTICS OF FISH PROTAMINES. VII \\ INTERACTION BETWEEN CLUPEINE SULFATE AND THE CYTOPLASMIC MEMBRANE \\ OF BACILLUS SUBTILIS
}

\author{
NAZRUL MD. ISLAM, TERUSHIGE MOTOHIRO,* \\ AND TAKAHISA KIMURA \\ Laboratory of Microbiology, Faculty of Fisheries, \\ Hokkaido University, Hakodate 041, Japan \\ * Laboratory of Food Quality Control and Analysis, \\ Faculty of Fisheries, Kagoshima University, \\ Kagoshima 890, Japan \\ (Received July 14, 1987)
}

\begin{abstract}
The interaction between clupeine sulfate (a protamine from herring milt) and the cytoplasmic membrane of Bacillus subtilis was investigated. Protoplasts of $B$. subtilis was lysed by clupeine and the lytic effect was directly proportional to the concentration of clupeine and time of exposure. The antibacterial action of clupeine was reversed by anionic phospholipids and the cell membrane of the bacterium. Clupeine was also found to bind and form a complex with the phospholipids. These results indicate that protamine bound primarily to the membrane phospholipids, which may result in damage to the membrane structure and function.
\end{abstract}

The antibacterial action of nuclear basic proteins from fish spermatozoa, known as protamines, has been studied for a long time (1-4), and some of the reports were reviewed by ANDO et al. (5). Recently, growth of gram-positive bacteria as well as outgrowth of their spores were found to be inhibited by fish protamines $(4,6,7)$. This has drawn the attention of food additive users. Among antibacterial agents which can be used in food technology, protamine has several unique features. For example, protamine, a natural polypeptide, occurs in fish milt and is odorless, colorless and almost tasteless. It is reported that protamine is nontoxic to laboratory animals when injected intraperitoneally $(8)$, and is hydrolyzable with digestive enzymes(9). For effective application in food technology it is

Address reprint requests to : Dr. T. Kimura, Laboratory of Microbiology, Faculty of Fisheries, Hokkaido Úniversity, 3-1-1 Minato-cho, Hakodate 041, Japan. 
important to know the mechanism of action of protamine.

So far, only a few attempts have been made to elucidate the mechanism of action of protamine and the molecular basis of protamine action is not known clearly. In 1944, NEGRONI and FisCHER (10) suggested that protamines act as cationic detergents, but provided no direct evidence. More recently, BELL and HesLot (11) reported the inhibition of protein and nucleic acid synthesis by protamine in Vicia faba roots, and the bacteriolytic action of protamine on different Bacillus species was found by ANTOHI and Popesco (19). Previously, we reported that clupeine binds to the isolated cell walls of B. subtilis, changes the cellular morphology, damages the cell membrane structures, and releases cytoplasmic materials (12).

Here, we describe investigations of the interaction between clupeine and cytoplasmic membrane of $B$. subtilis.

\section{MATERIALS AND METHODS}

Organism and growth condition. Bacillus subtilis IFO 3026 was used throughout this study and they were grown in either trypticase soy broth (TSB, Difco) or heart infusion broth (Difco) at $37^{\circ} \mathrm{C}$.

Chemicals. Clupeine sulfate (a protamine from herring milt) was obtained from Wako Ltd., lysozyme (from egg white), phospholipids, fatty acids and globulin were from Sigma Ltd. $\alpha$-L-dipalmitoyl $\left[1-{ }^{14} \mathrm{C}\right]$ phosphatidylethanolamine $(5.0 \mathrm{mCi} / \mathrm{mmol})$ was purchased from Amersham (England). All other chemicals were of reagent grade.

Preparation of protoplasts and cytoplasmic membrane. The protoplasts and cell membranes were prepared according to the method described by ROSENTHAL and MATHESON (13) with certain modifications. B. subtilis was grown to late log phase $(12 \mathrm{hr})$ at $37^{\circ} \mathrm{C}$ in TSB supplemented with $0.2 \% \mathrm{MgSO}_{4} \cdot 7 \mathrm{H}_{2} \mathrm{O}$. Cells were harvested, washed, and suspended ( $1 \mathrm{mg}$ of dry wt cells $/ \mathrm{ml}$ ) in $50 \mathrm{~mm}$ Tris- $\mathrm{HCl}$ buffer, pH 7.2, with $10 \mathrm{~mm} \mathrm{MgCl}_{2}$, stabilized by the addition of $30 \%$ sucrose and followed by treatment with $100 \mu \mathrm{g} / \mathrm{ml}$ lysozyme. During incubation for $1 \mathrm{hr}$ at $37^{\circ} \mathrm{C}$ with gentle shaking, protoplast formation was completed as controlled microscopically. Membrane suspensions were prepared by osmotic shock lysis of the protoplasts. After separation by centrifugation, the washed membranes were resuspended in $10 \mathrm{~mm}$ Tris- $\mathrm{HCl}$ buffer, $\mathrm{pH} 7.2$, containing $5 \mathrm{~mm} \mathrm{MgCl}_{2}$.

Antagonistic effect of isolated cell membranes and membrane components. Cell membrane and representative membrane components were mixed with clupeine and assayed for bactericidal action against B. subtilis by counting the viable cells. Samples without clupeine and antagonists served as controls.

Binding between clupeine and membrane phospholipids. Binding of clupeine to radioactive phospholipid was studied by the method of HUMmEL and DREYER (14) as described by STORM and Strominger (15). A phospholipid micelle was prepared by mixing and sonicating $4 \mathrm{nmol} \alpha$-L-dipalmitoyl $\left[1-{ }^{14} \mathrm{C}\right]$ phosphatidylethanolamine, 
$8.0 \mathrm{nmol}$ lecithin and $30.0 \mathrm{nmol}$ of cardiolipin in $0.1 \mathrm{~m}$ Tris, $\mathrm{pH} 7.5$. A $5 \mathrm{ml}$ Sephadex G-25 column was equilibrated with the phospholipid micelle. After the baseline radioactivity was established, $20 \mu \mathrm{g}$ of clupeine in $200 \mu \mathrm{l}$ of buffer containing phospholipid dispersion was added on the top of the column and the radioactivity of each $200 \mu$ l fraction collected was counted.

Thin layer chromatography. Ten $\mu \mathrm{g}$ of clupeine and $5 \mu \mathrm{mol}$ of $\alpha$-L-dipalmitoyl $\left[1-{ }^{14} \mathrm{C}\right]$ phosphatidylethanolamine were mixed and treated with in $10 \mathrm{~mm}$ Tris- $\mathrm{HCl}$ buffer, $\mathrm{pH} 7.0$, for $30 \mathrm{~min}$ at $37^{\circ} \mathrm{C}$. Thin layer chromatography was performed with DC-Alufolien cellulose 5522 TLC plates (Merck) and developed with a solvent system composed of chloroform-methanol- $\mathrm{NH}_{4} \mathrm{OH}(10 \%)(60: 35: 16, \mathrm{v} / \mathrm{v} / \mathrm{v})$. Radioactive spots were identified by autoradiography and clupeine was by ninhydrin.

\section{RESULTS}

\section{Effects of clupeine on protoplasts of B. subtilis}

We have reported that cellular morphology was changed accompanied with the release of cytoplasmic materials from the cells when clupeine was added to the cell suspension of $B$. subtilis (12). These results indicate that clupeine induces the disintegration of the membrane structure of $B$. subtilis. In order to explain this phenomenon, suspensions of $B$. subtilis protoplasts in $50 \mathrm{~mm}$ Tris- $\mathrm{HCl}$ buffer, $\mathrm{pH}$ 7.2 , containing $30 \%$ sucrose were treated with varying concentrations of clupeine,

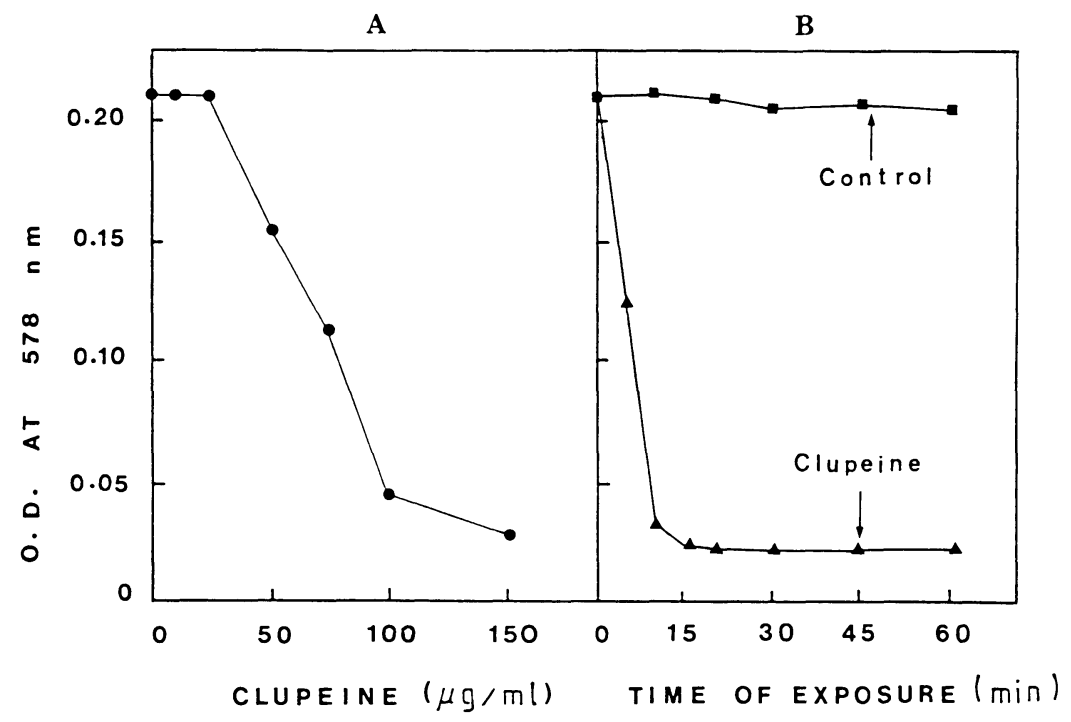

Fig. 1. Lysis of B. subtilis protoplasts by clupeine.

(A) Lysis of protoplasts equivalent to $1.0 \mathrm{mg}$ dry $\mathrm{wt}$ of cells $/ \mathrm{ml}$ by different concentrations of clupeine at $37 \mathrm{C}$ after $15 \mathrm{~min}$ exposure.

(B) Rate of lysis of protoplasts with $150 \mu \mathrm{g}$ of clupeine $/ \mathrm{ml}$. 
Table 1. Antagonistic effect of isolated cell membranes and typical membrane components on the bactericidal action of clupeine $(100 \mu \mathrm{g} / \mathrm{ml})$ against $B$. subtilis $\left(10^{3}\right.$ cells $\left./ \mathrm{ml}\right)$.

\begin{tabular}{lcc}
\hline Antagonist & $\begin{array}{c}\text { Concentration } \\
(\mu \mathrm{g} / \mathrm{ml})\end{array}$ & $\begin{array}{c}\text { Cell viability } \\
(\%)\end{array}$ \\
\hline $\begin{array}{l}\text { Isolated cell membrane } \\
\quad \text { B. subtilis })\end{array}$ & 10.0 & 95 \\
Phosphatidylethanolamine & 10.0 & 93 \\
Phosphatidylglycerol & 10.0 & 92 \\
Cardiolipin & 10.0 & 90 \\
Palmitic acid & 10.0 & 70 \\
Stearic acid & 10.0 & 65 \\
Arachidic acid & 10.0 & 68 \\
Globulin & $2.5 \mathrm{mg} / \mathrm{ml}$ & 0 \\
\hline
\end{tabular}

a There were no viable cells in the control plates without antagonist.

and the stability of the protoplasts was determined by measuring the decrease of optical density (O.D.) at $578 \mathrm{~nm}$ (Fig. 1). Decreased O.D. in the suspension indicated the lysis of protoplasts by clupeine, and the lytic effect was directly proportional to the concentration of clupeine and time of exposure. The rapid lysis of protoplasts indicate that clupeine interacted with cell membrane. Considering the highly cationic nature of clupeine, it appears that clupeine may interact specifically with anionic components of the cytoplasmic membrane.

\section{The antagonistic effect of isolated membranes and membrane components}

Isolated cytoplasmic membranes from B. subtilis and membrane components including phospholipids, fatty acids and protein were investigated for their antagonistic effect on the bactericidal action of clupeine. Table 1 shows that cell membrane, phospholipids and fatty acids were able to antagonize the antibacterial action of clupeine, particularly the phospholipids and cell membrane were very effective which restored the cell viability by more than $90 \%$. Whereas globulin had no effect. These results indicated that clupeine may interact primarily with the membrane phospholipids.

\section{Interaction between clupeine and phospholipid dispersions}

Interaction of clupeine with phospholipid was studied by gel filtration according to the method of Hummel and Dreyer (14). The phospholipids in the present study were in an aggregated (micelle) form in aqueous solutions and were excluded from Sephadex G-25. In the absence of clupeine, all the phospholipids ran in the void volume of the column. Figure 2 shows that addition of clupeine to the top of the column resulted in perturbations of the continuous flow of micelle from the baseline of the elution profile and produced a trough followed by a peak as evidenced by a decline in radioactivity followed by a gradual increase. It was 


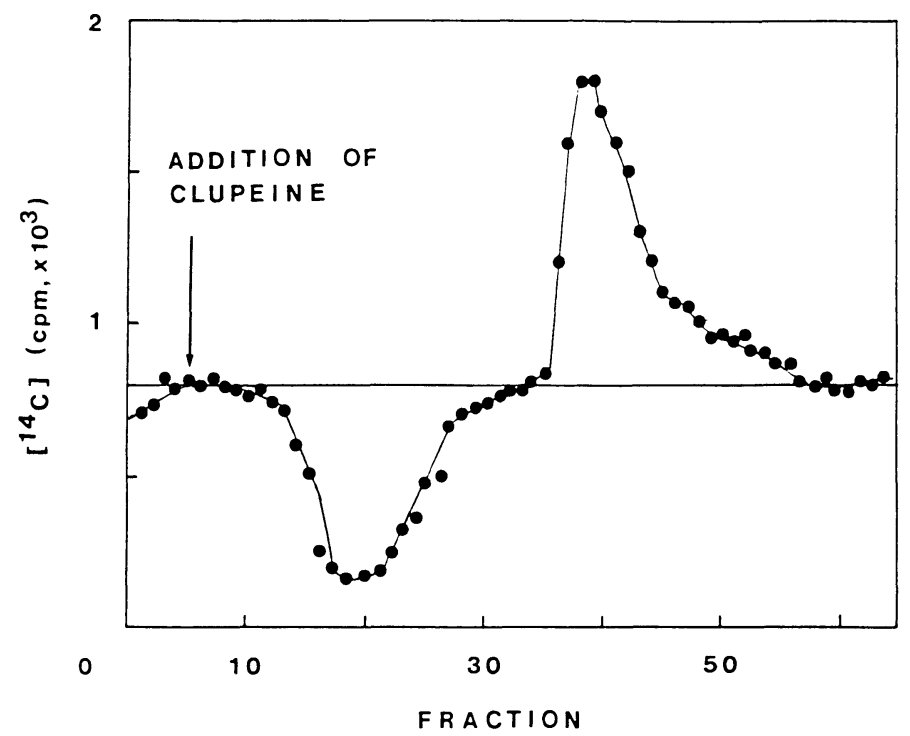

Fig. 2. Binding of clupeine with $\left[{ }^{14} \mathrm{C}\right]$ phosphatidylethanolamine. Phospholipid dispersion was prepared by sonication in $0.1 \mathrm{M}$ Tris, $\mathrm{pH} 7.5$, and passed through a $5 \mathrm{ml}$ Sephadex G-25 column. Clupeine was added at fraction 5 in buffer containing the ${ }^{14} \mathrm{C}$ phospholipid micelle and $200 \mu \mathrm{l}$ fractions were collected and counted.

Table 2. $R f$ values obtained from thin layer chromatographic (TLC) ${ }^{a}$ analysis of clupeine-phosphatidylethanolamine complex, clupeine and radioactive phospholipid substrate.

\begin{tabular}{ll}
\hline Compound & $R f$ values \\
\hline $\begin{array}{l}\left.\text { Clupeine-[dipalmitoyl- }{ }^{14} \mathrm{C}\right] \text { phosphatidylethanolamine } \\
\text { complex } \\
\begin{array}{l}\text { Clupeine } \\
{\left[\text { Dipalmitoyl }-{ }^{14} \mathrm{C}\right] \text { phosphatidylethanolamine }}\end{array}\end{array}$ & 0 \\
\hline
\end{tabular}

a TLC was performed with DC-Alufolien cellulose 5522 plates (Merck) and a solvent composed of chloroform-methanol- $\mathrm{NH}_{4} \mathrm{OH}(10 \%)(60: 35: 16, \mathrm{v} / \mathrm{v} / \mathrm{v})$.

assumed that clupeine disrupted the phospholipid aggregates such that some fraction of the phospholipid was included in the gel along with clupeine. Analysis of amino acids demonstrated that clupeine was found only in the peak of the radioactivity. These findings indicated that clupeine strongly interacted with the phospholipids included in the gel.

Formation of a clupeine-phospholipid complex could also be demonstrated by thin layer chromatography. After incubation of clupeine with radioactive phosphatidylethanolamine, the preparation was subjected to thin layer chromatography and the $R f$ values were compared with those of clupeine and radioactive phospholipid substrate. As shown in Table 2, the mixture of clupeine and radioactive phospho- 
lipid had an $R f$ value different from that of phospholipid or clupeine alone. This result also demonstrates that clupeine binds with the membrane phospholipids.

\section{DISCUSSION}

According to the results of our previous biochemical and morphological studies (12) and the rapid lysis of protoplasts presented here clupeine induces rapid and marked damage to the cell membrane of B. subtilis. The bactericidal action of clupeine may be related to the primary action of the drug on the membrane. Amounts of clupeine required for the lysis of bacterial protoplasts were the same as those required for the leakage of cytoplasmic constituents from intact cells (12). These results indicate that clupeine interacts primarily with the cytoplasmic membranes of bacteria and induces dissolution of membrane structure.

The interaction between clupeine and cell membrane was supported by the findings that isolated cell membranes and some membrane components antagonized the antibacterial action of clupeine, and more directly by the binding experiments with gel filtration and thin layer chromatography of clupeine-bound lipids. These results indicated that clupeine has a relatively strong affinity for phospholipids, but there is no conclusive evidence that this basic protein interacts exclusively with any specific phospholipid class. However, it appears that the action of clupeine is due to its polycationic charge. Clupeine is characterized by its highly basic nature due to presence of a large number of arginine residues (about $70 \%$ of all amino acid residues) and an isoelectric point of about 12(5). The ionic groups of the basic amino acids of clupeine may form electrostatic bonds with the phosphate group of the phospholipids. In addition, hydrophobic interaction of non-polar amino acids of clupeine with phospholipids should also be considered. HenNing et al.(16) reported similar observations with a polypeptide antibiotic nisin. PACHE et al. (17) also provided evidence that polypeptide antibiotics polymyxin $\mathrm{B}$ and gramicidin $\mathrm{S}$ interact electrostatically with the membrane phospholipids. Electrostatic interaction of clupeine and phospholipid may also be indicated by the fact that the high ionic strength of the medium inhibited the antibacterial action of clupeine (18).

The data presented here and in our previous paper (12) indicate that clupeine interacts strongly with membrane phospholipids, causing damage to the membrane and releasing the cytoplasmic constituents. These actions may destroy the metabolic function of the membrane. These factors are assumed to be the decisive events leading to the loss of cell viability. In an accompanying paper we describe the action of clupeine on a membrane-bound enzyme and membrane structure in relation to the molecular nature of clupeine action on bacterial cells.

\section{REFERENCES}

l) B. F. Miller, R. Abrams, R. Dorfman, and M. Klein, Science, 96, 426 (1942).

2) T. D. Brock, Can. J. Microbiol., 4, 65 (1958). 
3) O. R. BraekKan and Gj. Boge, Fiskeridirektorates Skifter ser. Teknol. Undersok., 4, 1 (1964).

4) M. N. Islam, T. Itakura, and T. Motohiro, Nippon Suisan Gakkaishi, 50, 1705 (1984).

5) T. Ando, M. Yamasaki, and K. Suzuki, In Protamines, 1st ed., Springer-Verlag, Berlin, Heidelberg, New York, (1973), p. 1.

6) M. N. Islam, T. Motohiro, and T. Itakura, Nippon Suisan Gakkaishi, 52, 913 (1986).

7) M. N. Islam, T. Motohiro, and T. Itakura, Nippon Suisan Gakkaishi, 52, 919 (1986).

8) W. C. Starbuck, R. A. Seibert, A. Schwartz, C. Mauritzen, C. W. Taylor, and H. Busch, Arch. Int. Pharmacodyn., 165, 374 (1967).

9) J. Kleczkowaski and A. Kleczkowaski, J. Gen. Microbiol., 14, 449 (1956).

10) P. Negroni and I. Fischer, Rev. Soc. Argentina Biol., 20, 489 (1944).

11) S. Bell and H. Heslot, Exp. Cell Res., 54, 77 (1969).

12) M. N. Islam, H. Oda, and T. Motohiro, Nippon Suisan Gakkaishi, 53, 297 (1987).

13) S. L. Rosenthal and A. Matheson, Biochim. Biophys. Acta, 318, 252 (1973).

14) J. P. Hummel and W. J. Dreyer, Biochim. Biophys. Acta, 63, 530 (1962).

15) D. R. Storm and J. L. Strominger, J. Biol. Chem., 249, 1833 (1974).

16) S. Henning, R. Metz, and W. Hammes, Int. J. Food Microbiol., 3, 121 (1986).

17) W. Pache, D. Chapman, and R. Hillaby, Biochim. Biophys. Acta, 255, 358 (1972).

18) M. N. Islam, T. Motohiro, and T. Itakura, Nippon Suisan Gakkaishi, 51, 811 (1985).

19) S. ANtohi and A. Popesco, Z. Naturforsch., 34C, 1144 (1979). 